\title{
SISTEM GOTONG ROYONG pada masyarakat baduY DI DESA KANEKES PROUINSI BANTEN
}

\author{
Mutual Help in Baduy People of Kanekes, Banten
}

\author{
Oleh Ria Andayani Somantri \\ Balai Pelestarian Sejarah dan Nilai Tradisional Bandung \\ Jl. Cinambo No.136 Ujungberung-Bandung \\ Email: riaandayanisomantri@yahoo.com
}

\begin{abstract}
Abstrak
Sistem Gotong-royong pada Masyarakat Baduy di Desa Kanekes, Provinsi Banten merupakan uraian tentang aktivitas gotong-royong yang hidup pada masyarakat Baduy di Banten. Aktivitas tersebut tercermin dalam tradisi nyambungan, yakni kebiasaan masyarakat Baduy mengirim atau menyumbang sesuatu kepada warga yang sedang menyelenggarakan hajatan atau pesta dengan sistem timbal balik (resiprositas); tradisi liliuran, yakni kebiasaan masyarakat Baduy yang lebih mengarah pada arisan tenaga untuk menyelesaikan suatu kegiatan atau pekerjaan; tradisi dugdug rempug, yakni kegiatan gotong-royong yang dilandasi keinginan spontanitas untuk membantu dan menolong pihak-pihak yang membutuhkan bantuan dan pertolongan mereka; dan tradisi tunggu lembur, yakni aktivitas sekelompok orang Baduy yang secara bersama-sama melakukan kegiatan menjaga lembur 'kampung' dari berbagai kemungkinan yang akan membahayakan keamanan kampung tersebut berikut isinya. Tradisi nyambungan, liliuran, dugdug rempug, dan tunggu lembur masih bertahan sampai sekarang, karena dipandang mampu mengatasi sejumlah persoalan, yang intinya membutuhkan suatu kerja sama antarsesama warga Baduy.
\end{abstract}

Kata kunci: gotong-royong, tradisi

\begin{abstract}
This research aims to describe some Baduy traditions that still exist today, which called nyambungan (giving donation to someone who has celebration), liliuran (collecting human resources to build something), dugdug rempug (spontaneous act to help others), and tunggu lembur (guarding their village from unexpected danger). They are all based on gotong-royong (working together to help each other). Theses traditions are preserved because they are considered solutions for many of their social problems.
\end{abstract}

Keywords: togetherness, traditions. 


\section{A. PENDAHULUAN}

Manusia tidak pernah bisa hidup sendiri secara absolut. Kontak sosial dan komunikasi, pada dasarnya diperlukan untuk memenuhi berbagai kebutuhan hidupnya dan menjaga kelangsungan hidup jenisnya. Dengan demikian, manusia senantiasa berada dalam suatu kehidupan bersama. Oleh karena itu, manusia disebut makhluk sosial, yang berarti manusia tidak dapat hidup tanpa berkelompok.

Dalam kehidupan bersama itulah terjadi interaksi sosial antarindividu. Interaksi sosial merupakan suatu proses yang menimbulkan hubungan timbal balik antarindividu dan antarkelompok, serta antara individu dan kelompok (Soekanto, 1983:45). Salah satu bentuk interaksi sosial yang terjadi dalam suatu kelompok sosial adalah interaksi sosial asosiatif yang mengarah pada kerja sama, seperti gotongroyong.

Koentjaraningrat (1982) mengartikan gotong-royong sebagai rasa saling membantu. Selanjutnya, dia menjelaskan bahwa gotong-royong terdapat pada banyak kebudayaan bangsa di dunia. Tidak hanya ada di Asia, melainkan juga di Afrika, Amerika Latin, bahkan di Eropa. Sejak zaman dulu, bangsa Indonesia sendiri telah mengenal aktivitas gotong-royong, yang hampir ada pada sebagian besar kebudayaan suku-suku bangsa di Indonesia. Aktivitas tersebut tercermin dalam berbagai aspek kehidupan masyarakat.

Cukup banyak aktivitas gotongroyong yang masih bertahan dalam bentuk dan perwujudan yang sama dari dulu sampai sekarang. Ada pula kegiatan gotong-royong yang bermetamorfosis dalam bentuk dan perwujudannya mengikuti perkembangan zaman dan kebutuhan para pendukungnya. Tak sedikit pula aktivitas gotong-royong yang mulai melemah karena berbagai alasan, misalnya karena melemahnya kesadaran masyarakat tentang manfaat gotong-royong. Tentu hal ini sangat disayangkan.

Pada dasarnya, dalam aktivitas gotong-royong tersirat konsep yang menganggap penting sikap tenggang rasa dan kepekaan untuk tidak berbuat semena-mena terhadap sesama manusia. Hal tersebut sangat penting untuk menanggulangi tekanan-tekanan masalah kehidupan masa kini. Dengan demikian, memungkinkan bagi orang Indonesia untuk bekerja sama dengan sesamanya secara mudah; untuk bersikap toleran terhadap sesamanya yang berkeyakinan dan berpendirian lain; dan untuk bekerja sama dengan bangsa lain. Oleh karena itu, tradisi gotong-royong yang hidup dalam berbagai kelompok sosial perlu dijaga dan dipelihara. Dasar pemikiran itulah yang melatarbelakangi dilakukannya penelitian tentang Sistem Gotong-royong pada Masyarakat Baduy di Desa Kanekes, Provinsi Banten.

Masalah dalam penelitian Sistem Gotong-royong pada Masyarakat Baduy di Provinsi Banten dirumuskan dalam beberapa pertanyaan berikut ini:

- Bagaimanakah wujud gotongroyong pada masyarakat Baduy?

- Dalam bidang apa saja kegiatan gotong-royong berlangsung pada masyarakat Baduy?

Adapun ruang lingkup penelitian tentang Sistem Gotong-royong pada Masyarakat Baduy di Desa Kanekes meliputi gambaran umum Desa Kanekes dan wujud aktivitas gotong-royong dalam berbagai aspek kehidupan, seperti perladangan, upacara, dan kehidupan sosial.

Gotong-royong merupakan aspek yang tidak terpisahkan dari kebudayaan. Kebudayaan adalah serangkaian nilai, aturan, pengetahuan, dan norma yang dimiliki oleh individu yang dipakai untuk memahami lingkungan hidupnya, baik lingkungan alam, lingkungan sosial, dan lingkungan binaan. Salah satu unsur kebudayaan yang bersifat universal adalah organisasi sosial. Menurut Bambang Rudito (2011), organisasi sosial merupakan sebuah manajemen budaya yang mengatur para anggota kelompok sosial untuk melakukan aktivitas tertentu dengan cara tertentu yang disepakati oleh kebu-dayaan yang berlaku. Manajemen budaya ini akan menjadi tradisi yang terus-menerus digunakan oleh kelompok sosial tersebut dalam usaha mempertahankan kebiasaan yang sudah turun-temurun.

Ada satu aspek penting dari studi organisasi sosial, yakni tentang pranata 
sosial. Selanjutnya Rudito menjelaskan, pranata sosial adalah aktivitas khusus manusia berkenaan dengan kebutuhan hidupnya yang dianggap penting, yang berupa rangkaian aturan dan hubungan antarsistem aturan dalam berinteraksi. Jadi, organisasi sosial dapat dijabarkan dalam beberapa pranata sosial seperti religi, ekonomi, kekerabatan, kesenian, bahasa, dan sebagainya.

Lebih lanjut Rudito menjelaskan bahwa organisasi sosial juga dapat beraktivitas sebagai gotong-royong. Koentjaraningrat (1982:130) mendefinisikan gotong-royong sebagai kerja sama di antara anggota-anggota suatu komuniti, dan beberapa penelitian menunjukkan bahwa nilai budaya gotong-royong ada korelasinya dengan kebudayaan agraris. Rudito membagi gotong-royong ke dalam beberapa bentuk, yakni tolong-menolong, kerja bakti, dan saling membantu.

Tolong-menolong, biasanya terkait dengan persoalan individu secara pribadi dalam kehidupan masyarakat, terutama berhubungan dengan pranata sosial yang berlaku, misalnya pranata sosial kekerabatan, seperti perkawinan. Dalam hal ini, ada warga yang membantu pekerjaan dalam menyelenggarakan perkawinan, dengan harapan suatu waktu orang yang telah dibantunya akan melakukan hal yang sama ketika ada pekerjaan yang serupa (balance reciprocity).

Kerja bakti, yaitu gotong-royong yang dilakukan anggota masyarakat untuk kepentingan bersama, seperti untuk kebersihan kampung atau desa; dan upacara yang berkaitan dengan keagamaan di kampung atau desa. Hal itu banyak dilakukan oleh anggota masyarakat. Sekarang, aktivitas tersebut biasanya bukan lagi berdasarkan pada suku bangsa, melainkan pada suatu wilayah administrasi.

Saling membantu, merupakan gotong-royong yang berkaitan dengan musibah salah seorang warga kampung, seperti peristiwa kematian di salah satu rumah penduduk. Para tetangga biasanya akan siap menolong dengan tidak mengharapkan apapun dari yang ditolong. Saling membantu juga bisa saja berupa barang yang bermakna religius (seperti zakat dan sedekah).

Penelitian tentang Sistem Gotongroyong pada Masyarakat Baduy di Desa Kanekes, Provinsi Banten merupakan jenis penelitian yang bersifat deskriptif yang bertujuan menggambarkan secara tepat sifatsifat suatu gejala sosial, baik individuindividu, kelompok-kelompok, dan keadaan sosial tertentu. Oleh karena itu, pendekatan yang sesuai untuk jenis penelitian deskriptif adalah pendekatan kualitatif.

$$
\text { Zulyani Hidayah }
$$

menjelaskan, pendekatan kua-litatif digunakan untuk memahami persoalan sosial atau budaya manusia berdasarkan pada suatu pengembangan gambaran yang kompleks dan holistis, dibangun dengan susunan katakata, menyajikan pandangan ditil dari informan dan dilaksanakan di lingkungan alamiahnya. Studi kualitatif juga dilaksanakan dalam situasi peneliti berinteraksi secara langsung dengan orang-orang yang diteliti, dalam upaya memperoleh data dari sumber pertama. Adapun teknik pengumpulan data yang digunakan di lapangan adalah pengamatan dan wawancara.

\section{B. HASIL DAN BAHASAN}

\section{Gambaran Umum Desa Kanekes}

Desa Kanekes merupakan wilayah adat masyarakat Baduy. Secara administratif, Desa Kanekes masuk dalam wilayah Kemantren Cisimeut, Kecamatan Leuwidamar, Kabupaten Lebak, Provinsi Banten. Luas Desa Kanekes adalah 5.108,85 Ha, dengan batas-batas yang mengelilingi desa tersebut dari berbagai arah mata angin adalah sebagai berikut:

- Di bagian utara berbatasan dengan Desa Bojongmenteng, Desa Cisimeut, dan Desa Nayagati. Ketiganya masuk dalam Kecamatan Leuwidamar;

- Di bagian selatan berbatasan dengan Desa Cikate yang masuk dalam wilayah Kecamatan Malimping;

- Di bagian barat berbatasan dengan Desa Parakanbeusi, Desa Pasirnangka, Desa 
Kebon Cau, dan Desa Karang Nunggal, yang masuk dalam Kecamatan Bojongmanik; dan

- Di bagian timur dibatasi oleh Desa Karang Combong dan Desa Sukajaya yang masuk dalam wilayah Kecamatan Muncang.

Letak Desa Kanekes berada di kawasan Pegunungan Kendeng, yang kondisi fisiknya berbukit-bukit. Curah hujan rata-rata tahunan selama dasawarsa terakhir umumnya melebihi $4.000 \mathrm{~mm} /$ tahun, kecuali dalam beberapa tahun saja yang hanya mencapai $3.000 \mathrm{~mm} /$ tahun hingga 4.000 $\mathrm{mm} /$ tahun. Curah hujan di Kanekes tertinggi dibanding tempat-tempat lain di wilayah Leuwidamar.

Desa Kanekes, diperkirakan dihuni oleh 10.941 jiwa yang terbagi menjadi 2.726 kepala keluarga dan tersebar di 59 kampung. Seluruh penduduk desa tersebut adalah urang Baduy atau orang Baduy. Dalam kehidupan sehari-hari, masyarakat Baduy menggunakan bahasa pengantar bahasa Sunda, yang dikategorikan sebagai bahasa Sunda dialek Sunda-Banten. Bahasa SundaBanten yang berlaku lebih spesifik lagi yaitu subdialek Baduy.

Sampai sejauh ini, ada kekhasan tersendiri dalam pengaturan tatanan kehidupan masyarakat Baduy sehari-hari. Pola pengaturan yang khas itu begitu dominan mengendalikan perilaku mereka dalam menciptakan harmoni kehidupan yang selaras, damai, dan sejahtera dalam perspektif mereka. Roda kehidupan masyarakat Baduy berputar terus mengikuti dua sistem pemerintahan yang berbeda, yakni sistem pemerintahan formal dan sistem pemerintahan informal.

Sistem pemerintahan formal mengacu pada sistem pemerintahan negara Republik Indonesia yang diberlakukan untuk mengatur seluruh desa di negeri ini. Sistem pemerintahan informal merujuk pada sistem pemerintahan lokal atau sistem pemerintahan adat yang secara tradisional mengatur kehidupan masyarakat Baduy dari generasi ke generasi. Sistem pemerintahan adat ini berupa lembaga kapuunan, yang mengharuskan masyarakat tunduk pada ketentuan adat yang dilaksanakan di bawah kendali pemimpin adat tertinggi, yakni puun.
Mata pencaharian masyarakat Baduy dapat dibedakan menjadi dua, yakni mata pencaharian utama dan mata pencaharian tambahan atau sampingan. Mata pencaharian utama mereka adalah bertani di lahan kering atau disebut ngahuma. Pekerjaan tersebut ditekuni oleh masyarakat Desa Kanekes secara keseluruhan. Sementara itu, mata pencaharian sampingan yang digeluti mereka untuk mengisi waktu luangnya, di antaranya menyadap nira dan membuat kerajinan anyaman atau rajutan, membuat gula aren, dan menenun kain khas Baduy.

Masyarakat Baduy menganut agama Sunda Wiwitan, yang menekankan pada penghormatan atau pemujaan kepada arwah nenek moyang atau karuhun dan kepercayaan kepada satu kuasa, yakni Batara Tunggal.

\section{Aktivitas Gotong-royong pada Masyarakat Baduy}

Ada beberapa aktivitas gotongroyong dalam kehidupan masyarakat Baduy, yang tercermin dalam aktivitas nyambungan, liliuran, dugdug rempug, dan tunggu lembur. Keempat aktivitas tersebut akan diuraikan satu persatu.

\section{a. Nyambungan}

Nyambungan dalam Kamus Basa Sunda memiliki arti mere naon-naon kanu ngayakeun sidekah atawa pesta 'memberi segala sesuatu kepada penyelenggara hajatan atau pesta'. Begitu juga dengan masyarakat Baduy yang mengartikan nyambungan sebagai aktivitas mengirim atau menyumbang sesuatu kepada warga yang sedang menyelenggarakan hajatan atau pesta. Di luar acara hajatan, kiriman seorang warga kepada warga lainnya tentu tidak disebut nyambungan. Dengan demikian, hajatan merupakan salah satu unsur penting dalam tradisi nyambungan.

Hajatan merupakan istilah umum yang meliputi berbagai bentuk selamatan atau kenduri. Selain itu, hajatan juga identik dengan sidekah, nyalametkeun atau syukuran. Orang Baduy biasanya menggelar hajatan setelah melangsungkan beberapa upacara daur hidup mereka, di antaranya upacara perkawinan atau khitanan. Sudah menjadi tradisi bahwa pelaksanaan berbagai hajatan biasanya berlangsung pada bulan 
kalima dalam kalender Baduy. Pada bulan tersebut, orang Baduy lebih banyak berada di rumah. Mereka sedang beristirahat setelah sekian lama menggarap ladang humanya masing-masing.

Tradisi nyambungan dalam hajatan didasari oleh keinginan untuk membantu sesama orang Baduy yang akan menyelenggarakan hajatan. Di balik bantuan itu, ada harapan agar dia mendapat perlakuan yang sama pada saat nanti menggelar hajatan. Mereka yang dibantu pun mengerti akan adanya keharusan untuk mengembalikan sumbangan itu pada saatnya nanti. Dengan demikian, keuntungan tetap akan dirasakan oleh kedua belah pihak, namun dalam waktu yang berbeda. Intinya, aturan main dalam tradisi nyambungan didasarkan pada azas timbal balik antara pemberi dan penerima sumbangan. Adapun tujuan nyambungan adalah untuk meringankan beban penyelenggara hajatan dalam memenuhi berbagai kebutuhan untuk hajatan.

Antara pemberi dan penerima sumbangan telah terjadi suatu kesepakatan. Bagi pemberi sumbangan, apapun yang diberikan akan menjadi tabungan yang tersimpan pada si penerima. Dia akan menerima tabungannya kembali kelak, ketika akan melaksanakan hajatan. Bagi penerima sumbangan, semua barang yang diterimanya akan menjadi utang dia kepada si pemberi. Dia memiliki kewajiban untuk membayar utang tersebut pada saat si pemberi akan melaksanakan hajatan nanti. Nilai utang yang dibayar, minimal setara dengan nilai pemberian dulu. Ketepatan memegang komitmen dalam nyambungan terkait erat dengan prestise atau harga diri. Kalaupun ada yang tak sanggup menunaikan kewajibannya untuk membayar utang, biasanya dia datang untuk meminta maaf kepada penyelenggara hajatan.

Bukan tidak mungkin ada pengalihan tanggung jawab utang kepada pihak lain. Kasus seperti itu biasanya terjadi jika penanggung jawab yang sebenarnya meninggal dunia. Jika terjadi hal demikian, tanggung jawab itu biasanya akan diambil alih oleh anak-anaknya. Merekalah yang selanjutnya memiliki kewajiban untuk melunasi utang orang tuanya sampai tuntas terkait dengan nyambungan.

Sumbangan yang diberikan kepada penyelenggara hajatan berasal dari satu keluarga atau mewakili satu kepala keluarga. Hal itu juga menjadikannya ciri keanggotaan dalam tradisi nyambungan. Mereka yang tergabung dalam kelompok nyambungan bukan bersifat individu melainkan mewakili satu keluarga atau kepala keluarga. Yang berperan dan muncul dari keluarga tersebut bisa istri maupun suami, namun umumnya istri yang paling berperan, karena terkait erat dengan urusan dapur.

Adapun keluarga lainnya yang sudah lama berumah tangga, mungkin saat ini ada yang berstatus sebagai pemberi sumbangan, penerima sumbangan, atau kedua-duanya, yakni sebagi pemberi sekaligus penerima sumbangan. Status pemberi sumbangan merujuk pada keluarga yang hanya bertindak sebagai penabung pada satu atau sejumlah keluarga lain. Ini berarti, keluarga tersebut belum pernah sekalipun menyelenggarakan hajatan. Status penerima sumbangan menunjuk pada keluarga yang bertindak sebagai penerima sumbangan dari satu atau sejumlah keluarga lain. Dalam hal ini, keluarga itu belum pernah memberi sumbangan sama sekali kepada keluarga lain, namun pernah menyelenggarakan hajatan. Keluarga yang memiliki status kedua-duanya, biasanya pernah memberi sumbangan kepada keluarga lain dan pernah menyelenggarakan hajatan.

Kesempatan untuk menjadi anggota kelompok nyambungan terbuka manakala ada hajatan, dan keluarga tersebut diundang oleh penyelenggara hajatan. Pada saat itulah, keluarga tersebut akan memberi sumbangan sebagai simpanannya pada penyelenggara hajatan, dan begitu seterusnya. Dengan demikian, setiap keluarga bisa menjadi penabung di sejumlah keluarga yang ada di Baduy. Semakin banyak keluarga yang disumbang, berarti semakin banyak pula simpanannya.

Kesempatan untuk keluar dari keanggotaan dalam nyambungan terbuka 
juga ketika ada acara hajatan. Komitmen antara pemberi dan penerima sumbangan akan berakhir ketika satu sama lainnya sudah saling membalas sumbangan atau utangnya telah terbayarkan.

Dalam aktivitas nyambungan, tidak ada ketentuan mengenai jenis barang yang akan disumbangkan. Umumnya, sumbangan yang diberikan kepada penyelenggara hajatan berupa berbagai keperluan hajatan, terutama bahan makanan dan makanan yang sudah jadi. Ada yang menyumbang bahan makanan mentahnya, seperti gula merah, garam, beras, kotok 'ayam', atau ikan asin. Banyak juga di antara mereka yang lebih memilih makanan jadi atau sudah matang, seperti pindang, dodol, dan wajit. Selain itu, ada juga yang menyumbang buah-buahan seperti pisang.

Jenis dan banyaknya sumbangan bergantung pada posisi atau status keluarga tersebut dalam kelompok nyambungan pada saat itu, apakah sebagai penabung atau pembayar utang. Jika keluarga tersebut akan bertindak sebagai penabung, pilihan jenis dan jumlah sumbangannya sangat terbuka lebar. Sebagai contoh, keluarga tersebut menyumbang gula merah dalam hajatan keluarga si A, garam dalam hajatan keluaga $\mathrm{B}$, dodol dalam hajatan keluarga $\mathrm{C}$, dan seterusnya. Tanpa terasa, keluarga tersebut memiliki simpanan yang beragam jenisnya.

Anggota yang tidak konsisten dalam membayar utangnya, tetap akan diketahui orang lain, karena ada petugas yang mencatatnya. Penyelenggara hajatan biasanya menunjuk seseorang yang pandai menulis untuk mencatat semua sumbangan yang masuk. Selain pandai menulis, orang tersebut juga dipercaya karena kejujurannya. Petugas ini pun bisa menjadi tempat bertanya orang Baduy yang mungkin lupa dengan apa yang pernah disumbangkan kepada sebuah keluarga penyelenggara hajatan.

Tugas yang diemban oleh pencatat sumbangan dalam kegiatan hajatan cukup penting. Dia harus mencatat nama-nama penyumbang, asal kampung, jenis sumbangan, banyaknya sumbangan, dan status penyumbang, apakah sebagai penabung atau pembayar utang. Sebetulnya, para pengirim sumbangan umumnya mengingat apa yang pernah disumbangkan kepada keluarga penyelenggara hajatan. Namun perkembangan terjadi ketika ada orang Baduy yang dapat menulis dan membaca. Petugas yang dulunya hanya mengingat, kini bertambah tugas tugas mencatat semua sumbangan agar tidak lupa. Catatan tersebut tidak hanya dimiliki petugas tadi, melainkan juga diserahkan kepada penyelenggara hajatan. Dengan demikian, fungsi pencatat sangat penting dan strategis dalam menjaga keteraturan dan alur status sumbangan yang masuk. Dalam hal ini, dia bertanggung jawab menjaga mekanisme kerja kelompok nyambungan.

Jika mengacu pada konsep gotongroyong dari Rudito, aktivitas nyambungan dapat dikategorikan kedalam bentuk tolongmenolong. Model gotong-royong seperti itu terkait dengan persoalan individu secara pribadi yang berhubungan dengan pranata sosial kekerabatan, seperti perkawinan dan khitanan. Dalam hal ini, ada warga yang membantu pekerjaan dalam menyelenggarakan perkawinan dan khitanan. Di balik bantuan tersebut tersirat harapan bahwa suatu waktu orang yang telah dibantunya akan melakukan hal yang sama ketika ada pekerjaan yang serupa (balance reciprocity). Bantuan yang diberikan lebih bersifat materi, berupa barang-barang yang diperlukan untuk hajatan.

\section{b. Liliuran}

Rutinitas kehidupan sehari-hari orang Baduy tampak relatif homogen. Mereka menjalani aktivitas berladang di huma, dari pagi hingga petang hari; mengisi waktu luang di antara kegiatan berladang dan mengurus rumah tangga dengan mengerjakan pekerjaan sampingan, seperti menyadap nira dan membuat kerajinan anyaman; melakukan aktivitas kemasyarakatan; serta melaksanakan serangkaian ritual adat, baik untuk kepentingan pribadi maupun untuk kepentingan bersama.

Beragam aktivitas yang harus dilakukan oleh mereka, tentu saja berbedabeda bobotnya. Ada kegiatan yang dipandang ringan, juga ada kegiatan yang tergolong berat untuk dikerjakan. Aktivitas yang ringan tentu akan mudah dijalaninya sendiri, atau dengan bantuan anggota 
keluarganya. Sementara itu kegiatan yang dikategorikan berat, cukup sulit untuk dikerjakan sekalipun dengan bantuan anggota keluarganya sendiri. Kalaupun itu dapat dikerjakan sendiri beserta anggota keluarganya, dipastikan akan membutuhkan waktu yang sangat lama. Oleh karena itu, mereka memerlukan tenaga kerja tambahan untuk menyelesaikan pekerjaan yang dianggap berat.

Ada dua cara yang dapat dilakukan untuk mengatasi kebutuhan tenaga kerja seperti itu. Pertama, mempekerjakan orang lain dengan cara mengupahnya, baik dalam bentuk uang maupun bentuk lainnya yang telah disepakati bersama. Yang kedua dengan cara liliiuran, yakni suatu mekanisme tradisional yang biasa dilakukan untuk mengatasi kekurangan tenaga kerja dalam menyelesaikan suatu aktivitas yang dianggap berat. Dalam hal ini, dia tidak perlu memberi upah kepada mereka. Tenaga mereka akan dibayar dengan tenaga juga pada saat mereka membutuhkannya, dalam kondisi yang sama seperti itu.

Liliuran menurut Kamus Basa Sunda adalah tutukeuran pagawean lantaran anu saurang aya halangan pikeun ngalampahkeun pagaweanana 'saling bertukar pekerjaan karena seseorang berhalangan untuk mengerjakan pekerjaan tersebut'. Dalam pengertian orang Baduy, liliuran lebih mengarah pada arisan tenaga untuk menyelesaikan suatu kegiatan atau pekerjaan.

Liliuran menjadi salah satu cara yang banyak dipilih orang Baduy untuk menyelesaikan satu kegiatan yang dianggap berat. Cara ini dipandang menguntungkan, karena mereka tidak dibebani kewajiban untuk memberi upah. Sebaliknya, justru mereka dapat saling membantu menyumbangkan tenaga untuk menyelesaikan kegiatan yang sama secara bergiliran. Dengan demikian, pekerjaan yang tadinya terasa berat menjadi lebih ringan dan lebih cepat selesai karena dikerjakan oleh banyak orang. Memang itulah tujuan yang paling mendasar dari apa yang disebut liliuran dalam kehidupan orang Baduy.

Orang Baduy umumnya mengenal liliuran sejak mereka kecil. Pemahaman tentang aktivitas liliuran dalam kehidupan orang Baduy sudah ditanamkan kepada anak-anak di dalam lingkungan keluarga. Para orang tua membimbing mereka dalam masalah ini sejak anak-anak berusia dini atau memiliki teman bermain. Pembinaan aktivitas liliuran ditujukan kepada mereka tanpa terkecuali, baik terhadap anak lakilaki maupun anak perempuan. Hal itu sangat mungkin dilakukan, karena mereka sejak kecil dibiasakan terlibat dalam pekerjaan orang tuanya, mengajak berladang di huma misalnya.

Layaknya anak-anak, para orang tua pun memberi kesempatan kepada anak lakilaki maupun anak perempuannya untuk bermain. Umumnya, mereka membentuk kelompok bermain dengan teman-teman sebayanya. Ada kelompok bermain anak laki-laki, juga ada kelompok bermain anak perempuan. Jumlah anak yang tergabung dalam kelompok bermain itu minimal ada tiga orang. Mereka dapat berkumpul dalam satu kelompok bermain tentu karena beberapa alasan, seperti rumahnya saling berdekatan, umurnya sebaya, dan satu sama lain memiliki penilaian positif yang membuat mereka merasa cocok, aman, dan nyaman untuk bergaul secara intensif.

Kelompok bermain merupakan arena sosial pertama yang dimanfaatkan orangtua untuk mengaktualisasikan aktivitas liliuran pada anak-anak. Aktivitas yang akan dikerjakan secara liliuran dalam kelompok bermain tersebut disesuaikan dengan usia mereka, misalnya mengambil kayu bakar dan bahan makanan di huma. Anak laki-laki dan anak perempuan memang lazim diminta untuk mencari kayu bakar dan bahan makanan di huma oleh orang tuanya. Sebagai ucapan terima kasih, mereka akan disuguhi kue-kue atau bahkan dijamu makan. Hal yang sama juga akan dilakukan ketika ada anggota lainnya dalam kelompok bermain tersebut mendapat tugas yang sama. Seperti itulah pengalaman awal dalam melakukan aktivitas liliuran.

Liliuran dalam kelompok bermain seperti itu umumnya dapat dipertahankan hingga mereka beranjak remaja bahkan sampai berumah tangga, karena menemukan 
kecocokan satu sama lainnya. Kalaupun ada kesalahpahaman dalam bergaul, mereka dapat mengatasinya dengan baik. Oleh karena itu, keberadaan kelompok liliuran itu pun dapat dipertahankan sampai sekian lamanya.

Kemungkinan lain adalah terjadi pengurangan anggota dalam kelompok liliuran tersebut, bisa karena rasa bosan, terjadi kesalahpahaman, atau mereka sudah tidak tinggal lagi di kampung yang sama. Kalaupun seseorang keluar dari keanggotaan kelompok tersebut, dia tetap akan mencari kelompok liliuran yang baru. Dengan demikian, akan terjadi penambahan anggota pada kelompok liliuran yang lain.

Menjadi anggota suatu kelompok liliuran dipandang perlu karena terdapat banyak manfaat di dalamnya. Beberapa keuntungan yang dapat dirasakan oleh anggota kelompok tersebut, di antaranya menjalin dan memperkuat ikatan persahabatan atau pertemanan, mempererat keakraban, dapat saling membantu dalam pekerjaan, dan melestarikan tradisi leluhur. Oleh karena itu, setiap warga Baduy Dalam akan menjadi bagian dari suatu kelompok liliuran.

Kelompok liliuran yang ada di Baduy, jumlahnya lebih dari satu. Ada kelompok liliuran di kalangan anak-anak, remaja, juga orang dewasa. Hampir tidak ditemukan kelompok liliuran yang anggotanya terdiri atas laki-laki dan perempuan. Setiap kelompok liliuran yang ada di sana hanya mewakili satu jenis kelamin, laki-laki saja atau perempuan saja. Cukup banyak anggota yang tergabung ke dalam setiap kelompoknya, bahkan bisa mencapai 17 s.d. 20 orang.

Seseorang yang telah tergabung dalam suatu kelompok liliuran akan terikat oleh satu kesepakatan yang tidak tertulis, terutama terkait dengan hak dan kewajibannya sebagai anggota. Dia berhak dibantu oleh anggota lainnya jika akan melakukan aktivitas yang telah disepakati bersama. Adapun kewajibannya adalah ikut serta membantu anggota lain yang akan mengerjakan aktivitas yang telah disepakati bersama. Selain itu, dia harus memiliki kemampuan dan pengetahuan untuk menger- jakan semua aktivitas yang telah disepakati bersama pula.

Ada kemungkinan seorang anggota kelompok liliuran tidak dapat memenuhi kewajiban yang seharusnya dilaksanakan terhadap anggota lainnya. Itu akan diterima selama alasannya sangat masuk akal, sangat penting, dan tidak dapat ditunda lagi. Misalnya, dia absen dari kegiatan liliuran untuk salah satu anggota kelompok tersebut karena sakit parah. Jika terjadi hal seperti itu, tetap harus ada pemberitahuan kepada anggota yang menyelenggarakan acara liliuran. Pemberitahuan tersebut sekaligus permohonan maaf karena tidak dapat terlibat dalam acara liliuran tersebut.

Dalam suatu kelompok liliuran biasanya terdapat seseorang yang dituakan oleh seluruh anggota kelompok. Dia dituakan karena beberapa faktor, seperti usianya cukup senior, dan memiliki kemampuan untuk memimpin dengan tegas juga bijaksana. Dia harus menjadi pengendali keteraturan dan kelangsungan kelompok tersebut. Tugas yang diembannya antara lain menerima informasi dan menyebarkan informasi jika ada anggota yang akan menyelanggarakan kegiatan; mengatur jadwal kegiatan liliuran; mengingatkan dan menegur anggota yang lalai menjalankan kewajibannya.

Seseorang yang dituakan memang mengatur kelancaran semua aktivitas liliuran, tetapi bukan berarti dia yang menentukan tata urut pelaksanaan liliuran, apakah si A, si B, atau si C dahulu. Keputusan mengenai hal itu sepenuhnya diserahkan kepada anggota kelompok liliuran. Siapapun boleh menentukan jadwalnya sendiri, asal dia sudah memiliki kesanggupan untuk melaksanakannya. Sudah menjadi tradisi di Baduy, penyelenggara liliuran biasanya akan menjamu seluruh anggota kelompok liliuran yang telah bekerja untuknya. Mereka akan diberi makan dan minum sesuai dengan kemampu-an penyelenggara liliuran sendiri. Itulah yang dimaksud dengan kesanggupan untuk melaksanakan liliuran. Jika kesanggupan itu belum ada, seorang anggota tidak akan berani mengajukan jadwal liliurannya.

Aturan main seperti itu berlaku untuk semua kelompok liliuran, baik di 
kalangan anak-anak, remaja, dan orang dewasa. Pembicaraan tentang jadwal liliuran biasanya berlangsung dalam satu kumpulan informal. Embrio dari kelompok liliuran adalah kebiasaan berkumpul santai antarteman sebaya yang sudah akrab satu sama lainnya. Mereka berkumpul sambil melepas lelah setelah bekerja di ladang atau melaksanakan rutinitas sehari-hari. Berbagai tema perbincangan bergulir dalam kumpulan tersebut, termasuk juga mengenai jadwal liliuran. Bagaimanapun jadwalnya, dapat dipastikan semua anggota akan mendapat giliran melaksanakan liliuran.

Semua aktivitas yang dikerjakan secara liliuran berada dalam ranah kepentingan pribadi, dan bukan kepentingan umum ataupun untuk kepentingan pemimpin adat mereka. Meskipun demikian, tetap ada kepentingan pribadi yang jenisnya sama, dan harus dilakukan dalam kurun waktu yang sama oleh semua anggota kelompok liliuran. Kepentingan pribadi yang seperti itu sifatnya menjadi sesuatu yang rutin harus dipenuhi. Selain itu, ada juga kepentingan pribadi yang sama jenisnya, namun tidak perlu terpenuhi dalam kurun waktu yang bersamaan karena dipengaruhi oleh berbagai faktor. Dengan demikian, aktivitas tersebut lebih bersifat temporer.

Setiap kelompok liliuran, sudah pasti memiliki sejumlah kegiatan yang akan dilaksanakan oleh anggotanya. Jenis kegiatan tersebut akan berbeda antara kelompok liliuran di kalangan anak-anak, remaja, dan dewasa. Perbedaan antara kelompok liliuran anak-anak dan kelompok liliuran lainnya cukup jelas. Adapun perbedaan antara kegiatan yang dilakukan kelompok liliuran remaja dan dewasa sangatlah tipis bahkan cenderung relatif sama. Perbedaan yang paling tampak adalah antara kelompok liliuran laki-laki dan kelompok liliuran perempuan. Kesamaan biasanya terlihat pada kelompok liliuran remaja pria dan dewasa pria. Kalaupun ada perbedaan, itu hanya terletak pada jumlah kegiatan yang sedikit lebih banyak pada kelompok dewasa.

Jenis kegiatan yang dilaksanakan oleh setiap kelompok liliuran bisanya sesuai dengan tingkatan usia mereka, juga sesuai dengan jenis kelamin mereka. Artinya pekerjaan tersebut merupakan pekerjaan yang sudah biasa dilakukan oleh mereka. Pada kelompok liliuran remaja dan dewasa, khususnya di kalangan kaum pria, terdapat aktivitas yang dilakukan secara rutin oleh seluruh anggotanya. Dikatakan rutin karena aktivitas tersebut akan dilaksanakan berulang terus menerus setiap tahun. Aktivitas rutin tersebut meliputi berbagai kegiatan yang berhubungan erat dengan mata pencaharian utama mereka. Berladang, itulah kegiatan pokok dan tugas yang wajib dilakukan masyarakat Baduy. Hampir semua orang, kecuali jompo dan orang sakit, terlibat dalam berbagai kegiatan di ladang.

Kegiatan berladang terikat oleh aturan waktu dan adat yang berlaku untuk semua warga masyarakat Baduy. Oleh karena itu, mereka tidak bisa sembarang waktu melakukan kegiatan berladang. Ada beberapa tahapan kegiatan berladang yang dilakukan oleh orang Baduy, yakni narawas, yaitu memilih lahan untuk dijadikan huma; nyacar, yaitu kegiatan menebas rumput atau semak belukar, menebang pohon-pohon kecil, dan memangkas dahan-dahan pohon besar agar lahan memperoleh sinar matahari yang banyak; nukuh, yaitu mengeringkan rumput, dedaunan, potongan ranting, dan hasil tebasan lainnya dengan cara dijemur; ngahuru, yaitu membakar ranting-ranting yang sudah kering, setelah sebelumnya memisahkan batang-batang yang akan dijadikan kayu bakar; ngaseuk, yaitu membuat lubang untuk menanam benih padi dengan menggunakan aseuk (tugal); menanam padi atau disebut muuhan; ngirab sawan, yaitu mengusir segala macam gangguan; dibuat (panen); ngunjal, yakni mengangkut hasil panen padi dari huma menuju kampung untuk disimpan dalam lumbung padi atau leuit.

Tidak semua kegiatan dilakukan secara liliuran, karena dapat ditangani seluruh anggota keluarga. Tahapan kegiatan berladang yang dikerjakan secara liliuran yaitu nyacar, nuaran, ngaseuk, dan ngored. Kegiatan liliuran di bidang itu biasanya menjadi agenda rutin kelompok liliuran pemuda dan laki-laki dewasa. 
Mekanisme kerja kegiatan liliuran rutin dimulai dengan menentukan jadwal penggiliran. Sebetulnya, kegiatan rutin itu terikat dengan jadwal yang sudah ada, misalnya nyacar biasanya dilakukan pada bulan kalima. Selama bulan itu pulalah aktivitas liliuran nyacar untuk setiap anggota kelompok dilaksanakan. Waktu acara liliuran biasanya berlangsung dari pukul 08.00 WIB hingga pukul 16.00 WIB. Mereka datang ke tempat yang dituju sambil membawa alat kerjanya masing-masing. Dalam rentang waktu tersebut, mereka bisa bekerja di satu atau lebih dari satu anggota. Hal itu bergantung pada jumlah anggota liliuran yang ikut terlibat, dan luas lahan yang digarap oleh mereka. Selama menjalankan kewajibannya, mereka berbagi tugas sedemikian rupa agar pekerjaan dapat diselesaikan secara efektif dan efisien. Usai melaksanakan liliuran di satu anggota, mereka akan dijamu makan oleh penyelenggara liliuran.

Liliuran terus berjalan sampai semua anggota mendapat giliran untuk satu pekerjaan yang sama. Mekanisme kerja seperti itu pun akan berulang kembali ketika tiba pada musim ngaseuk dan musim ngored. Mekanisme kerja ini menjadi siklus tahunan yang rutin dilaksanakan oleh seluruh anggota kelompok liliuran.

Pelaksanaan liliuran yang bersifat temporer biasanya disesuaikan dengan kebutuhan anggotanya. Jenis kegiatan yang sering dilakukan oleh kelompok liliuran laki-laki dewasa adalah berhubungan dengan persiapan membangun atau memperbaiki rumah. Setiap anggota kelompok liliuran laki-laki dewasa pasti akan dihadapkan pada kebutuhan untuk membangun rumah atau memperbaiki rumah. Pekerjaan mendirikan rumah atau merenovasi rumah bukan hal yang mudah. Itu adalah pekerjaan berat yang memerlukan tenaga kerja, material, dan dana yang tidak sedikit. Karena alasan itulah, pekerjaan tersebut menjadi pekerjaan bersama. Ada yang dikerjakan secara liliuran, ada juga yang dilakukan secara gotong royong kerja bakti.

Jatuh tempo waktu untuk memenuhi kebutuhan akan hal itu, mungkin ada yang sama dan mungkin pula berbeda antara anggota yang satu dan anggota lainnya. Hal itu bergantung pada kondisi rumah yang ada, masih layak atau tidakkah untuk ditempati; juga bergantung pada kemampuan menyiapkan materialnya serta kesanggupan untuk melaksanakan liliuran. Hal yang sudah menjadi tradisi, segala sesuatu yang berhubungan dengan kegiatan membangun dan memperbaiki rumah biasanya dilakukan sekitar bulan kalima. Pada saat itu, mereka sedang terbebas dari rutinitas kegiatan berladang.

Jika kebutuhan untuk membangun rumah atau memperbaiki rumah sudah mendesak, ada beberapa persiapan yang biasa dikerjakan dengan cara liliuran. Hal itu meliputi pekerjaan sebagai berikut:

- Mengambil bahan bangunan, yakni mencari bahan-bahan bangunan di leuweung lembur (hutan yang ada di sekitar kampung yang bersangkutran). Jika di sana tidak menemukan bahan yang dicari, pencarian dapat dilakukan ke tempat lain. Bahan-bahan untuk membuat rumah yang biasa digunakan adalah kayu albasiah, $k a d u$ 'durian', dan duku. Kayu-kayu tersebut akan digunakan untuk membuat tiang dan rangka; kiray atau rumbia dan ijuk pohon kawung atau aren, yang akan digunakan untuk membuat atap; $a$ w $i$ 'bambu', yang akan digunakan untuk membuat giribig 'bilik' dan palupuh 'lantai'.

- Nutus, yakni membuat atap kiray. Khusus untuk atap kiray, seringkali si pemilik rumah telah menyiapkannya jauh hari sebelumnya. Pembuatan atap biasanya dimulai dengan pengambilan daun kirai 'rumbia' di luar kampung. Daun-daun rumbia yang telah disisir dari pelepahnya, diikat dan dibawa ke rumah. Pada waktu-waktu senggang, lembar demi lembar daun dirangkai menjadi atap. Ada kalanya pula atap dibuat pada waktu senggang di ladang.

- Membuat giribig 'bilik' untuk dinding rumah, yang pembuatannya diawali dengan mengambil bambu di luar kampung. Bambu-bambu sepanjang kirakira 4 s.d. 5 meter digotong ke rumah. Pada waktu senggang, bambu-bambu dibelah hingga tipis lalu dianyam menjadi sebuah giribig. Ukuran giribig dibuat sedikit lebih besar dari ukuran bidang 
rumah yang akan ditutupi. Setelah dijepit pada tiang dinding rumah, sisanya baru dipotong. Pemotongan kadang-kadang dilakukan sebelum dipasang, karena giribig telah diukur dengan tepat.

- Memuat palupuh 'lantai', yang juga dilakukan jauh hari sebelumnya.

Dari keempat kegiatan tersebut, mencari bahan bangunan termasuk yang jarang dilakukan, karena orang tidak dapat membangun rumah sekehendak hati. Dalam hal ini, khususnya di tangtu, puun ikut menentukan boleh tidaknya mendirikan rumah. Sementara itu untuk tiga kegiatan lainnya, biasanya ada saja satu atau beberapa anggota yang mengerjakannya secara liliuran dalam satu tahun. Frekuensi kegiatan nutus lebih sering, karena mereka harus mengganti atap kiray yang rusak secara periodik.

Mekanisme kerja liliuran untuk keempat jenis kegiatan tadi, tidak jauh berbeda dengan mekanisme liliuran pada aktivitas yang rutin dilakukan. Setiap rencana untuk melakukan kegiatan tersebut biasanya mengemuka ketika anggota kelompok liliuran sedang berkumpul. Kegiatan berkumpul biasa dilakukan karena mereka merupakan teman-teman sepergaulan yang cukup dekat dan akrab satu sama lainnya. Dari sana akan diketahui siapa saja yang akan melaksanakan liliuran untuk kegiatan khusus. Selanjutnya, proses liliuran pun berjalan.

Kegiatan liliuran di kalangan lakilaki memang lebih banyak dari aktivitas liliuran di lingkungan perempuan. Umumnya, kelompok liliuran perempuan menggarap pekerjaan yang ada urusannya dengan dapur, seperti mengambil bahan makanan, mengambil daun, dan menumbuk padi. Selain itu, ada juga liliuran dalam kegiatan menenun kain.

Sebetulnya, kaum perempuan, khususnya di tangtu Cibeo tidak punya kebiasaan menenun kain sendiri, kecuali untuk keperluan puun. Di sana ada satu alat tenun yang khusus untuk menenun kain keperluan puun atau untuk keperluan upacara adat. Termasuk dalam hal ini ketika ada seorang gadis yang akan menikah, puun melalui jaro akan meminta kelompok liliuran gadis tersebut untuk membuat selendang dan kain untuk keperluan upacara perkawinan. Mereka pun akan segera mengerjakan tugas tersebut secara liliuran menggunakan alat tenun tadi. Mereka berbagi tugas untuk menyelesaikan tenunannya.

Jika mengacu pada konsep gotongroyong yang dikemukakan oleh Rudito, liliuran dapat dikategorikan kedalam bentuk tolong-menolong, khususnya dalam aktivitas ngahuma 'berladang'. Berladang adalah mata pencaharian utama masyarakat Baduy, yang masih dilakukan secara tradisional. Aturan adat memagari mereka untuk tidak mengadopsi teknologi modern yang dapat mempermudah mereka menyelesaikan suatu pekerjaan. Padahal dalam kegiatan berladang, terdapat tahapan pekerjaan yang cukup besar dan berat. Pekerjaan tersebut tentu saja memerlukan tenaga kerja yang cukup banyak, di luar anggota keluarga petani. Masalah seperti itu dapat diselesaikan dengan tradisi liliuran. Dalam hal ini, seluruh anggota kelompok liliuran saling menolong untuk mengatasi kekurangan tenaga kerja agar dapat menyelesaikan pekerjaan besar dan berat dalam waktu yang singkat. Pertolongan yang diberikan berupa sumbangan tenaga dengan prinsip balance reciprocity.

\section{c. Dugdug Rempug}

Dugdug rempug adalah kegiatan gotong-royong yang dilandasi keinginan spontanitas untuk membantu dan menolong pihak-pihak yang membutuhkan bantuan dan pertolongan mereka. Bantuan yang diberikan bisa dalam bentuk tenaga atau materi. Hal itu bergantung pada bidang pekerjaan yang akan diselesaikan dengan cara gotong royong, apakah lebih memerlukan bantuan tenaga ataukah materi, atau mungkin kedua-duanya. Umumnya, bantuan tenagalah yang lebih banyak diperlukan dalam kegiatan dugdug rempug.

Seorang pemimpin adat, dalam hal ini jaro, menjadi pemimpin dan penanggung jawab pada sebagian besar kegiatan dugdug rempug yang ada di wilayah Baduy. Sebagai pemimpin, dia yang menentukan jadwal untuk melaksanakan dugdug rempug, tentu 
atas seizin puun. Dia pun menghimbau warganya agar ikut berpartisipasi dalam kegiatan dugdug rempug. Dia juga memberi teladan bagi warganya dengan cara terjun langsung dalam kegiatan tersebut.

Kegiatan dugdug rempug yang biasanya dipimpin oleh jaro, antara lain membuat atau memperbaiki cukangan 'jembatan bambu' dan rawayan; memindahkan lesung berukuran besar; babad jalan, yakni membuka dan memelihara jalan-jalan yang akan dan biasa dilalui oleh masyarakat Baduy; membangun dan memperbaiki rumah puun, rumah jaro, tampian dan bale; khusus untuk rumah pribadi, hanya pada bagian tertentu saja yang dilakukan secara dugdug rempug, misalnya pada saat mendirikan bangunan.

Aktivitas dugdug rempug juga dilakukan dalam mengerjakan huma serang dan huma puun. Aturan adat menetapkan, huma serang adalah lahan huma milik adat, yang pengerjaan, pemeliharaan, dan pemungutan hasilnya dilakukan secara bersamasama antara warga tangtu dan warga panamping yang sesuai dengan tangtu sembahannya, dan pelaksanaannya dipimpin oleh puun. Contohnya, untuk kegiatan ngaseuk di huma serang, setiap keluarga biasanya mengirimkan satu orang wakilnya yang akan terlibat dalam kegiatan dugdug rempug untuk mengerjakan huma serang. Mereka datang sambil membawa beras dua liter dan alat kerjanya masing-masing. Dalam kegiatan tersebut banyak sekali orang yang terlibat, juga sarat dengan pelaksanaan upacara-upacara adat.

Adapun huma puun adalah lahan huma yang diperuntukkan bagi puun dan keluarganya selama menjabat sebagai puun. Mereka yang terlibat dalam kegiatan dugdug rempug menggarap huma puun adalah warga masyarakat di sekitarnya. Kegiatan tersebut memang tidak diwajibkan, namun masyarakat di sekitarnya berupaya untuk ambil bagian dalam pekerjaan tersebut. Jumlah warga yang terlibat dalam kegiatan ini tidak sebanyak orang yang terlibat dalam kegiatan di huma serang.

Aktivitas dugdug rempug juga dilakukan dalam acara upacara adat, baik yang bersifat pribadi, seperti upacara sunatan, perkawinan, dan kematian; dan upacara yang bersifat komunal atau melibatkan seluruh warga Baduy. Dalam acaraacara tersebut, cukup banyak pekerja-an yang dikerjakan secara dugdug rempug oleh kaum wanita, seperti nutu 'menumbuk padi' dan mengolah makanan. Sementara itu kesibukan kaum laki-laki dalam hajatan adalah mendapat tugas mengolah makanan dari kotok 'ayam'. Mereka bertugas memanggang ayam yang akan dihidangkan untuk para tamu. Pekerjaan tersebut biasanya akan dikerjakan di luar kampung agar tidak kotor.

Ketika peristiwa kematian atau kaparupuhan seseorang di Baduy, warga kampung serta kerabat berdatangan menunjukkan rasa duka cita dengan membawa beras, kelapa, gula aren atau makanan yang sudah siap dihidangkan. Selain itu, mereka pun menyingsingkan baju dan mengulurkan tangan membantu segala sesuatu terkait dengan pengurusan jenazah dan upacara penguburan. Selain itu, mereka juga bergotong royong membantu keluarga yang ditinggalkan untuk keperluan hajatan kematian.

Jika mengacu pada konsep gotongroyong yang dikemukakan oleh Bambang Rudito, aktivitas dugdug dapat dikategorikan ke dalam bentuk kerja bakti. Ada kerja bakti yang bertujuan untuk kepentingan bersama, dan mengekspresikan kepatuhan pada pemimpin adat. Khusus untuk aktivitas dugdug rempug ketika ada peristiwa kematian, hal itu dapat dikategorikan kedalam bentuk saling membantu.

\section{d. Tunggu Lembur}

Gotong-royong lainnya adalah dalam bidang keamanan kampung. Mereka tetap mewaspadai berbagai macam kemungkinan yang akan mengganggu ketentraman hidup mereka. Sumber ketidakamanan itu berasal dari kebiasaan mereka pergi meninggalkan rumah untuk berladang di huma. Kalau saja lahan huma mereka berada dekat dengan kampung, tentu mereka bisa pulang pada sore harinya. Sebaliknya jika huma mereka jauh dari kampung, dipastikan mereka tidak mungkin pulang setiap hari ke rumah yang ada di kampung. Mereka biasanya akan menginap di saung huma dalam kurun waktu tertentu. Kebiasaan berladang 
seperti itu membuat kampung mereka menjadi sepi, minimal pada siang hari. Kalaupun rumah tidak kosong, penghuninya adalah para jompo dan orang yang sedang sakit.

Hal yang paling dikhawatirkan adalah masalah api tungku yang berada di dalam setiap rumah di Baduy. Seharusnya, pemilik rumah sudah mengamankan tungku perapiannya, ketika mereka meninggalkan rumah. Namun, bukan tidak mungkin ada di antara mereka yang lupa mengamankannya. Jika hal itu sampai terjadi, akan berakibat fatal. Bukan hanya rumah itu yang akan dilalap api, melainkan seisi kampung pun akan ikut terbakar. Rumah mereka yang berkonstruksi kayu memang sangat rentan terhadap bahaya kebakaran. Selain itu, para jompo dan orang sakit yang tinggal di rumah sepanjang hari, juga perlu mendapat perhatian. Padahal anggota keluarga lainnya, pergi meninggalkan rumah menuju ladang. Meskipun sangat kecil kemungkinannya, orang asing yang berniat buruk bisa saja memasuki wilayah kampung mereka. Oleh karena itu, kampung mereka haruslah dijaga untuk mengantisipasi hal-hal yang tidak diinginkan.

Menjaga keamanan kampung adalah kewajiban dan tanggung jawab semua orang yang tinggal di Baduy. Akan tetapi, tidak mungkin semua orang harus menjaga kampungnya setiap hari atau dalam waktu yang bersamaan. Bagaimanapun juga, mereka harus tetap meninggalkan rumah untuk pergi berladang, karena itulah tugas mereka yang paling utama. Ada mekanisme tradisional yang berfungsi untuk mengantisipasi dan mengatasi persoalan-persoalan tersebut, yakni tunggu lembur.

Tunggu lembur menunjuk pada aktivitas sekelompok orang yang secara bersama-sama melakukan kegiatan menjaga lembur 'kampung' dari berbagai kemungkinan yang akan membahayakan keamanan kampung tersebut. Tunggu lembur identik dengan kegiatan siskamling atau ronda. Aktivitas tersebut sepenuhnya berada di bawah tanggung jawab dan pengawasan sesepuh kampung. Dia memiliki kewenangan untuk menjaga dan mengendalikan kelangsungan jalannya aktivitas tunggu lembur.

Kegiatan tunggu lembur wajib dilakukan setiap hari selama 24 jam penuh, tetapi tidak perlu semua orang menjaga kampung setiap hari. Kewajiban tersebut diatur secara bergilir dengan seadil mungkin untuk setiap keluarga. Orang yang bertugas mewakili keluarga tersebut biasanya kepala keluarga atau anak laki-lakinya yang sudah cukup umur. Dia tidak sendirian, karena paling tidak masih ada kira-kira 14 (empat belas) orang lainnya yang mendapat jadwal yang sama. Jadi, dalam setiap harinya ada sekitar 15 orang pria yang bertugas menjaga keamanan kampung.

Mekanisme kerjanya diserahkan kepada ke-15 orang tadi, apakah mereka akan bersama-sama terus selama sehari semalam; atau akan membaginya menjadi beberapa jam kerja. Tugas mereka adalah berkeliling kampung secara periodik untuk mengontrol rumah-rumah warga, terutama tungku perapiannya; memperhatikan warga yang tinggal di dalam rumah di kampung, misalnya memberi makan jompo dan mengontrol orang yang sedang sakit; dan mengawasi kalau-kalau ada orang asing yang masuk ke wilayah mereka.

Bertugas selama sehari semalam atau selama 24 jam penuh bukanlah waktu yang singkat. Di sela-sela menjalankan tugasnya mereka biasanya mengobrol bersama, dudurukan atau menyalakan kayu bakar, memasak air untuk membuat minuman, membakar makanan untuk dimakan, atau melakukan kegiatan tertentu. Beberapa kegiatan yang biasa dilakukan selama bertugas tunggu lembur, di antaranya nutus 'membuat atap kiray', memotong rotan, dan pekerjaan sampingan lainnya, yang dilakukan pada siang hari. Dengan demikian, mereka masih tetap bisa berkarya meski sedang bertugas tunggu lembur.

Jika mengacu pada konsep gotongroyong yang dikemukakan oleh Rudito, aktivitas tunggu lembur dapat dikategorikan kedalam bentuk kerjabakti, khususnya dalam bidang keamanan kampung. Tradisi tunggu lembur sangat berkaitan erat dengan kegiatan berladang, yang seringkali dilakukan 
harus dengan meninggalkan rumah untuk sementara waktu. Selain itu, tradisi tunggu lembur juga merupakan wujud tanggung jawab sosial antarsesama warga Baduy yang tinggal dalam satu kampung yang sama. Warga yang tidak produktif untuk berladang karena sudah tua atau sakit, tetap terjaga keselamatan dan keamanannya ketika warga lainnya pergi berladang.

\section{PENUTUP}

Masyarakat Baduy di Desa Kanekes, Kecamatan Leuwidamar, Kabupaten Lebak, Provinsi Banten masih menjunjung tinggi nilai gotong-royong. Dalam kehidupan mereka, nilai gotong-royong tercermin dalam sejumlah tradisi yang dilakukan dalam berbagai aspek kehidupan. Ada tradisi nyambungan, yakni gotong-royong dalam kegiatan hajatan; ada tradisi liliuran, yaitu gotong-royong dalam kegiatan berladang dan beberapa kegiatan lainnya; ada tradisi dugdug rempug, yakni gotong-royong yang mengarah pada kerjabakti untuk kepentingan bersama (misalnya membangun jembatan dan membuka jalan), kepentingan adat (seperti upacara adat), dan kepentingan warga lainnya (seperti hajatan dan peristiwa kematian); dan ada tradisi tunggu lembur, yakni gotong-royong dalam bidang keamanan kampung.

Ada beberapa hal yang menarik dari semua tradisi yang bernafaskan kegotongroyongan itu. Pertama, hampir semua tradisi tersebut berhubungan, baik langsung maupun tidak langsung dengan kegiatan utama mereka, yakni berladang yang menjadi nafas kelangsungan hidup mereka. Kedua, aktivitas gotong-royong senantiasa dilakukan berdasarkan jenis kelamin yang sama, perempuan saja atau laki-laki saja. Jarang ditemukan kegiatan gotong-royong yang dilakukan oleh laki-laki dan perempuan secara bersamaan dalam waktu dan tempat yang sama sehingga mereka tampak berbaur. Bahkan ada di antaranya tradisi kegotongroyongan yang menjadi bagian integral dari pola pengasuhan anak pada masyarakat Baduy. Tradisi tersebut adalah liliuran, yang sudah diajarkan sejak dini oleh para orang tua kepada anak-anaknya.
Sekalipun tradisi nyambungan, liliuran, dugdug rempug dan tunggu lembur merupa-kan aktivitas gotong-royong yang terdapat dalam kehidupan masyarakat Baduy, tradisi tersebut diharapkan dapat menginspirasi masyarakat di luar itu untuk mengaplikasi-kan nafas kegotongroyongan tersebut dalam kehidupan sehari-hari.

\section{DAFTAR SUMBER}

1.Buku

Garna, Judistira. 1990.

Pendekatan Kualitatis dalam

Penelitian dalam Metode

Penelitian: Filsafat Penelitian dan

Pendekatan Kualitatif. Bandung:

Program Pascasarjana UNPAD.

Gunadi, Dade. 2001.

Kebiasaan Makan Pada Orang

Baduy di Desa Kanekes

Kecamatan Leuwidamar, Kabupaten Lebak. Propinsi

Banten. Bandung: Jurusan

Antropologi UNPAD.

Hidayah, Zulyani. 2006. Metodologi Penelitian "Kepercayaan"

Masyarakat. Jakarta: Penataran

Tenaga Teknis Pamong.

Koentjaraningrat. 1982.

Ihtisar Sejarah Pendidikan di

Indonesia dan Perubahan

Orientasi Nilai Budaya Indonesia.

dalam Koentjaraningrat 'Masalahmasalah Pembangunan. Jakarta:

LP3ES.

1989.

Metode Wawancara, dalam

Metode-metode Penelitian

Masyarakat. Jakarta: PT

Gramedia.

Makmur K, Ade. 2006.

Revitalisasi / Aktualisasi Nilai-nilai

ajaran Kepercayaan terhadap

Tuhan Yang Mahaesa. Bandung: 
Sarasehan Kepercayaan terhadap

Tuhan Yang Mahaesa.

Permana, Cecep Eka. 2006.

Tata Ruang Masyarakat Baduy. Jakarta: Wedatama Widya Sastra.

Rahardjo, Djoko Muji. 2002.

Urang Kanekes di Banten Kidul.

Jakarta: Proyek Pemanfaatan

Kebudayaan Direktorat Tradisi dan

Kepercayaan, Deputi Bidang

Pelestariandan Pengembangan

Budaya, Badan Pengembangan

Keudayaan dan Pariwisata.

Rangkuti, Nurhadi (penyunting). 1988.

Orang Baduy dari Inti Jagat.

Yogyakarta: Bentara Budaya

bekerja sama dengan Harian

Kompas, Etnodata, Yayasan

Promosi Indonesia, Yayasan Budhi

Dharma Pradesa.

Rozak, Abdul.2005.

Teologi Kebatinan Synda: Kajian

Antropologi Agama tentang Aliran

Kebatinan Perjalanan. Bandung: PT

Kiblat Buku Utama.

Siahaan, Tambun. 1982.

Prinsip Dalihan-na-tolu dan

Gotong-royong pada Masyarakat

Toba. dalam Koentjaraningrat

'Masalah-masalah Pembangunan.

Jakarta: LP3ES

Soekanto, Soerjono. 1983.

Beberapa Teori Sosiologi tentang

Struktur Masyarakat. Jakarta:

Rajawali.

Suhada. 2003.

Masyarakat Baduy dalam Rentang Sejarah. Banten: Dinas Pendidikan Provinsi Banten.
Pengertian, Konsep, dan

Kerangka Penulisan Organisasi

Sosial Gotong-royong.

Rahayu. 2006.

Beberapa Hal tentang Kepercayaan terhadap Tuhan Yang Mahaesa. Bandung: Penataran Tenaga Teknis Pamong.

\section{Makalah}

Bambang Rudito. 2011 